\title{
Chapter 17 \\ Land Use Planning as a Green \\ Infrastructure in a Rural Japanese \\ Depopulated Town
}

\author{
K. Watanabe and K. Ishida
}

\begin{abstract}
The purpose of this study is to show land use considering green infrastructure (GI) in a Japanese depopulated rural district. First, we classified six zones of the target area, depending on inundation risk, living environment, and area of each land use, by cluster analysis. As a result, we showed three characteristics of land use. These are the central built-up area with high disaster risk and high land price, the east side area with low disaster risk, and the paddy field area with high disaster risk. Next, we estimated the probability of vacant houses by logistic regression analysis. Based on the results and the six classified zones, we showed the area with high probability of vacant houses and high disaster risk. This area was observed at the central built-up area. Considering future depopulation, such a housing area in the central built-up area needs to shrink.
\end{abstract}

Keywords Inundation risk - Depopulated town - Cluster analysis · Land use planning

\subsection{Introduction}

Japanese population decline started from 2008 (Chino, 2009). After that, population has been continuously migrating from provincial cities to big cities. In particular, depopulation of small coastal towns and agricultural villages continues. Historically, most of Japanese built-up areas have been developed in coastal areas and plains. These are useful for the farming or water transportation, but these areas have much

\footnotetext{
K. Watanabe $(\bowtie)$

Research Center for Management of Disaster and Environment/Department of Civil and Environmental Engineering, Graduate School of Technology, Industrial and Social Sciences, Tokushima University, Tokushima, Japan

e-mail: kojiro@tokushima-u.ac.jp

K. Ishida

Faculty of Business and Commerce, Kansai University, Osaka, Japan
}

F. Nakamura (ed.), Green Infrastructure and Climate Change Adaptation, Ecological Research Monographs, https://doi.org/10.1007/978-981-16-6791-6_17 
inundation disaster risks. Since the advent of modern society, many structures made of concrete or other materials have been constructed to provide protection from a variety of disasters. In addition, recently, disaster mitigation for urban structures of land use control has been focused on. Green infrastructure (GI) is an important element of the land use plan.

In Japan, compact city policy is proceeding to make sustainable cities by utilizing limited resources. In many depopulated cities in Japan, it is difficult to arrange enough social infrastructure, due to financial problems. Therefore, it is necessary to relocate built-up areas in a more compact manner inside in a safe location. Since 2020, Act on Special Measures concerning Urban Reconstruction (Ministry of Land, Infrastructure, Transport and Tourism, Japan) has been promoted. As a foundation of the act, it is considered that natural disasters will become worse in Japan. The act includes land use control policy considering disaster risk.

Recently, natural disasters in Japan have become more severe; therefore, we need to change the urban structure utilizing GI also. Multifunction of GI is useful to solve some problems in depopulated areas. There are many places with GI functions, such as farmland, forest, vacant lot, etc., in depopulated localities. But recently, areas of unmanaged farmland or unmanaged forest have been increasing. Maintenance of such land use depends on the original character which is important to mitigate disaster risk. It can also contribute to a good natural landscape as regional resources. Thus, GI has an important role in sustainability of Japanese depopulated cities.

The purpose of the paper is to show land use policy with GI in a depopulated area. The target area is Zenzo River basin in Kaiyo town, Tokushima Prefecture, Japan. Kaiyo town is a Japanese depopulated municipality with a large forest area. Osato district is the central area in Kaiyo town. It is a plain area surrounded by mountain, river, and beach. Zenzo River is a tributary of Kaifu River; the basin overlapped Osato district. The target area has some disaster risks. These are building collapse and tsunami caused by the predicted Nankai Trough earthquake and inundation disaster from Kaifu River due to heavy rain. Tokushima Prefecture has assumed the seismic intensity level of 8 to 9 in Kaiyo town caused by Nankai Trough earthquake, and the probability of this earthquake is shown as a $70 \%$ within 30 years (Tokushima Prefecture Government 2013). Based on this assumption, many projects about disaster mitigation have been conducted.

Figure 17.1 shows land use of the target area. The target area is a suitable area utilized for GI of disaster mitigation because major land use is paddy fields and farmland. The built-up area is located along the roadside of national highway 55 and the east side of the target area. Population of the town has decreased from 8131 in 2005 to 6546 in 2015. Figure 17.2 shows that the population under 14 years old is decreasing, but population over 65 is increasing. The same trend is occurring in many Japanese provincial cities and towns. 


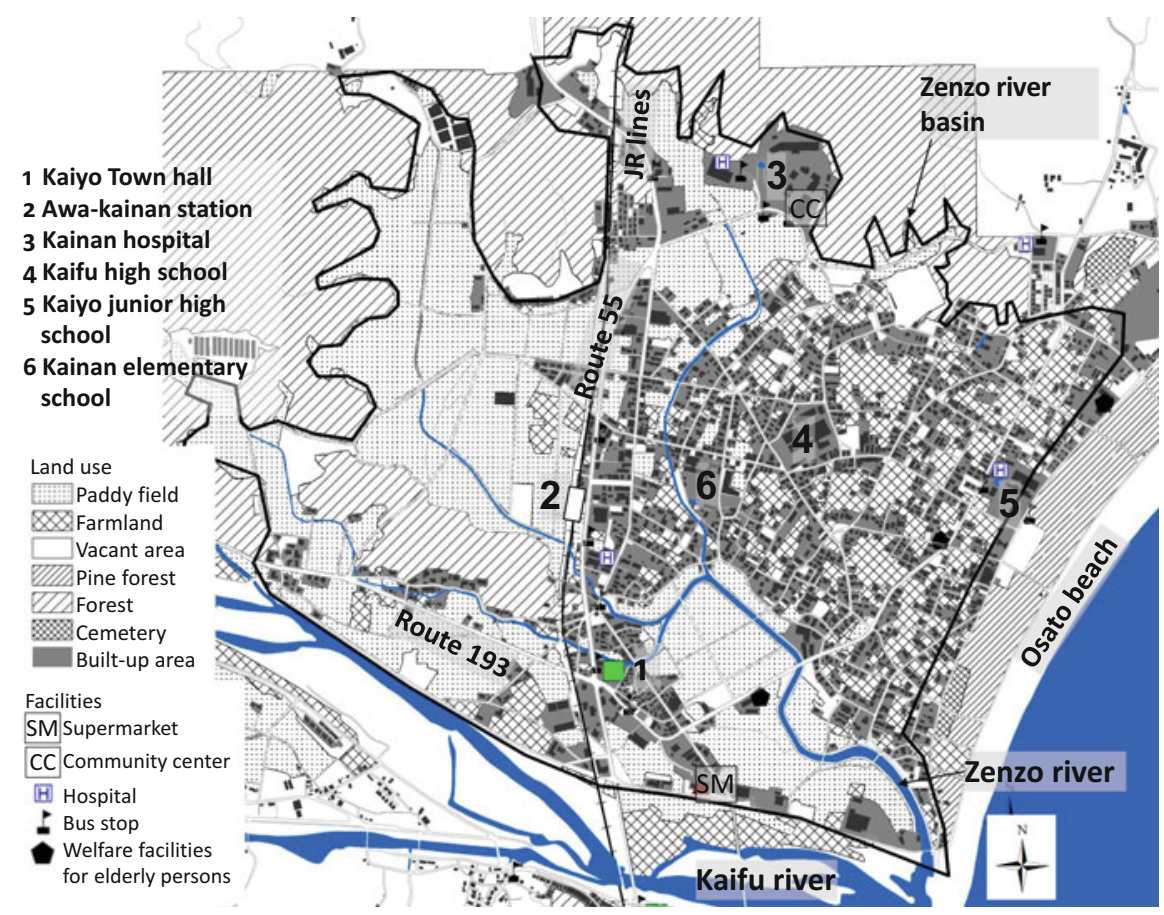

Fig. 17.1 Target area

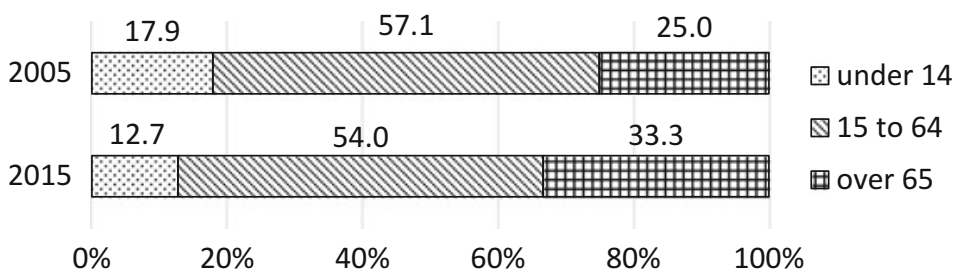

Fig. 17.2 Population ratio for each age group in the target area in 2005 and 2015

\subsection{Disaster Risk and Living Environment}

We classified the target area according to land characteristics, to show future land use trend. Elements of the classification are disaster risk, living environment, land use, and elevation. We used the housing damage level caused by inundation disaster as a disaster risk. Living environment index is used to show the potential of future residential location. Cluster analysis was conducted using these data, with a unit of 50 meters grid cell. 
Table 17.1 Damage level for houses by inundation depth

\begin{tabular}{l|l|l|l|l}
\hline & $<0.5 \mathrm{~m}$ & $0.5-0.9 \mathrm{~m}$ & $1.0-1.8 \mathrm{~m}$ & $>1.8 \mathrm{~m}$ \\
\hline Damage level & 0.144 & 0.205 & 0.452 & 1.000 \\
\hline
\end{tabular}

As disaster risk, we used two types of hazard, the river inundation (hazard 1) depth and the surface water inundation (hazard 2) depth. Hazard 1 shows the river inundation depth caused by inundation from Kaifu River by rainfall intensity having a recurrence interval of 50 years. This data is openly available at the website of National Land Numerical Information in Japan. ${ }^{1}$ Hazard 2 shows the estimated surface water inundation depth caused by typhoon No. 14 in 2014 named "Fengshen" (Yokokawa et al. 2020).

Table 17.1 shows the damage level of houses according to inundation depth. We calculated the level for each grid cell, in Table 17.1 (Ministry of Land, Infrastructure, Transport and Tourism 2010; Disaster Management group in Cabinet office of Japan 2021). Hereafter, we show the damage level for houses by river inundation depth as risk 1 and damage level for houses by the surface water inundation depth as risk 2.

Figure 17.3 shows the inundation area caused by Kaifu River mainly distributes over the west side of target area. Over $3 \mathrm{~m}$ inundation area is observed at the south side area of Zenzo River. These areas are covered with paddy field. Inundation depth at the roadside of national highway 55 is estimated to be 0.5 to $2 \mathrm{~m}$. Because the highway is a trunk road in the area, there are many commercial facilities in vicinity. It is important to manage the embankment of Kaifu River and to arrange evacuation facilities and routes. There is no inundation area on the east side. Elevation of this area is higher than others, so inundation from Kaifu River cannot reach the area.

Figure 17.4 shows that the surface water inundation area distributes for all areas diffusively. As is the same in Fig. 17.3, estimated surface water is observed at the paddy fields to the west side of the station and the south area of Zenzo River. If these paddy fields were to be changed to some other type of land use, the surface water will move to other areas. Such paddy fields are important to mitigate the flood disaster (Muto et al. 2018).

Table 17.2 shows the rate of the number of houses in the inundation area. In data of $\mathrm{A}$ in the table, it can be seen that $50 \%$ of houses are located in the non-inundation area, but $36 \%$ of houses are located in the $1.0-2.0 \mathrm{~m}$ and $2.0-3.0 \mathrm{~m}$ inundation area.

\footnotetext{
${ }^{1}$ https://nlftp.mlit.go.jp/ksj/
} 


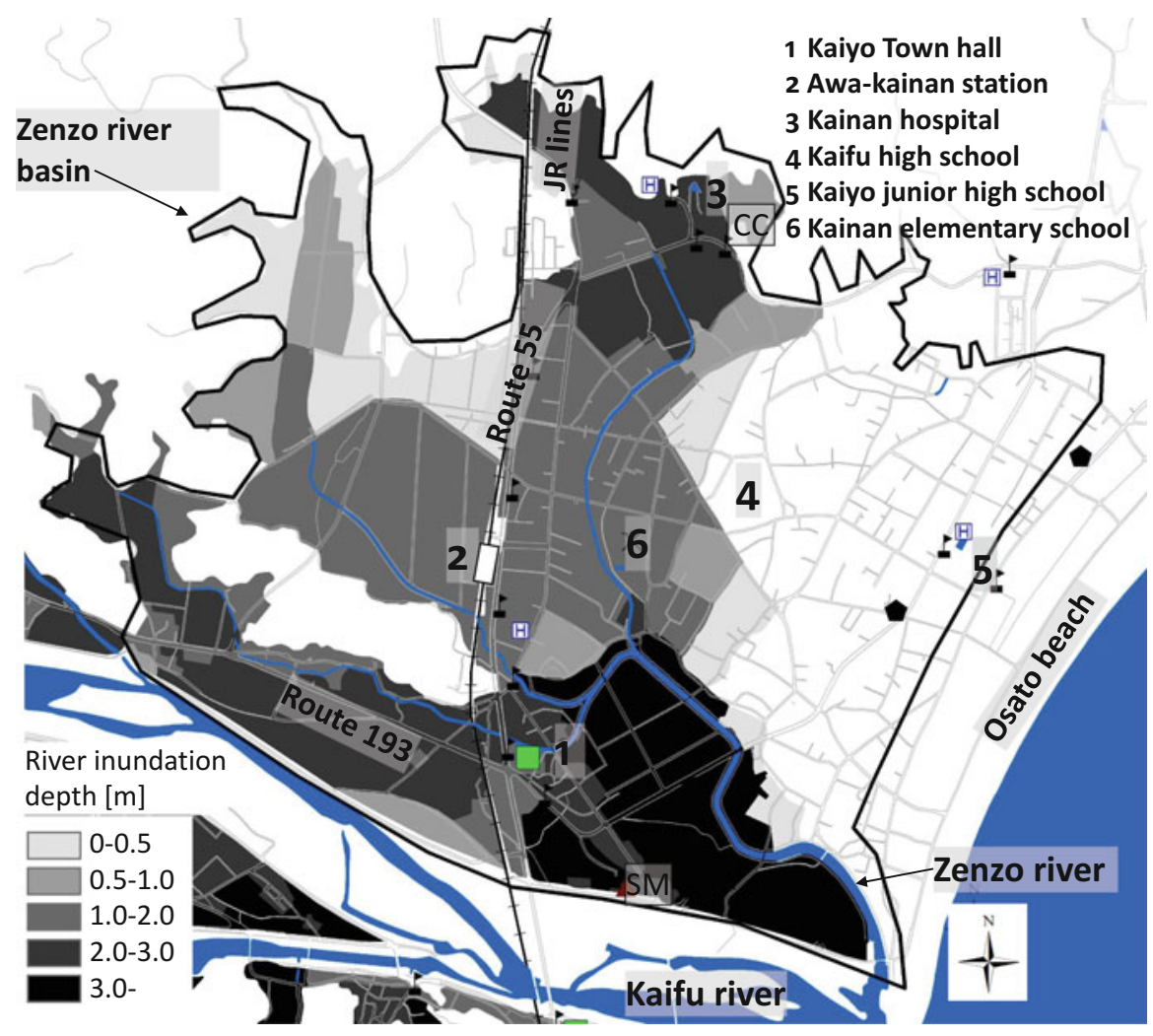

Fig. 17.3 River inundation depth (hazard 1)

Figure 17.3 shows the inundation area with 1.0-3.0 m includes a trunk road and town hall. Houses in this area need migration measures in order to protect them against inundation. In data of B in the table, it is evident that $78 \%$ of houses are located in the under $0.5 \mathrm{~m}$ inundation area. Although inundation depth is less than river inundation depth, Fig. 17.4 shows the inundation area is wide and diffusive. Therefore, it will result in surface water inundation over a large area.

Next, we calculated the living environment index. This index shows convenience level of living environment. We used the estimated land price as an alternative index of convenience level. According to the capitalization hypothesis, effect of infrastructure development is reflected as a land price increase. Based on the hypothesis, because it was assumed that areas with sufficient infrastructure have a good living environment, we estimated the land price to show convenience level.

Because there is no land price data for the all target areas, land price was estimated by multi-regression analysis. Objective variables were land prices of residential areas in depopulated areas of Shikoku Island region. This data shows the selected land prices used as an indicator, made by Japanese central and 


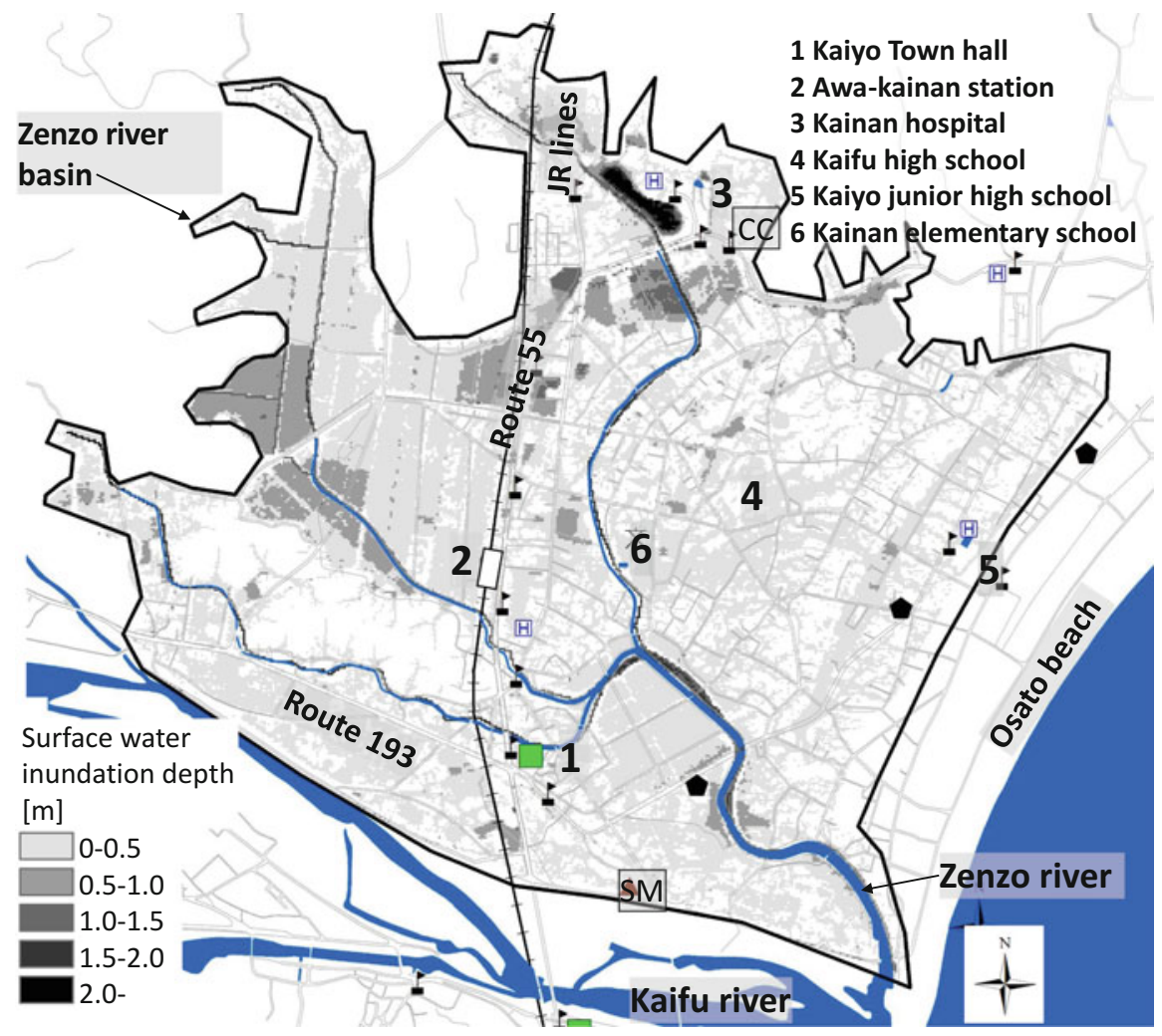

Fig. 17.4 Surface water inundation depth (hazard 2)

Table 17.2 Rate of number of houses in inundation area

\begin{tabular}{l|l|l|l|l|l|l|l|l}
\hline \multicolumn{2}{c|}{} & \multicolumn{3}{l|}{ Inundation depth } & \multicolumn{2}{l|}{ Total } \\
\cline { 2 - 10 } \multicolumn{2}{c}{} & no inundation & $<0.5 \mathrm{~m}$ & $0.5-1.0 \mathrm{~m}$ & $1.0-2.0 \mathrm{~m}$ & $2.0-3.0 \mathrm{~m}$ & $>3.0 \mathrm{~m}$ & \\
\hline \multirow{3}{*}{$\mathrm{A}$} & 2006 & 49.5 & 6.7 & 6.8 & 26.1 & 9.9 & 1.0 & 100 \\
\cline { 2 - 10 } & 2018 & 49.5 & 7.0 & 6.8 & 25.5 & 10.2 & 0.9 & 100 \\
\cline { 2 - 9 } & $2018-2006$ & 0.0 & 0.3 & 0.0 & -0.6 & 0.3 & -0.1 & \\
\hline \multirow{3}{*}{ B } & 2006 & 20.2 & 78.1 & 0.7 & 0.7 & 0.2 & 0.0 & 100 \\
\cline { 2 - 9 } & 2018 & 20.3 & 78.0 & 0.8 & 0.8 & 0.2 & 0.0 & 100 \\
\cline { 2 - 9 } & $2018-2006$ & 0.0 & -0.1 & 0.0 & 0.1 & 0.0 & 0.0 & \\
\hline
\end{tabular}

A: Rate of the number of houses in river inundation area [\%].

B: Rate of the number of houses in surface water inundation area [\%]. 
Table 17.3 Results of multi-regression analysis for land price estimation

\begin{tabular}{|c|c|c|c|c|c|}
\hline & & Estimate & Std. Error & $\mathrm{t}$ value & $\operatorname{Pr}(>|t|)$ \\
\hline \multicolumn{2}{|l|}{ (intercept) } & 15550.69 & 1336.29 & 11.64 & 0.000 \\
\hline \multicolumn{2}{|c|}{ Population in 2010} & 27.30 & 1.83 & 14.91 & 0.000 \\
\hline \multicolumn{2}{|c|}{ Elevation } & -18.84 & 4.86 & -3.88 & 0.000 \\
\hline \multirow[t]{5}{*}{ Distance from } & Town hall and community center & -1.02 & 0.85 & -1.19 & 0.234 \\
\hline & Elementary school & -0.23 & 0.56 & -0.41 & 0.685 \\
\hline & Medical facilities & -1.13 & 0.47 & -2.40 & 0.017 \\
\hline & Bus stop & -0.53 & 0.42 & -1.24 & 0.215 \\
\hline & \multicolumn{5}{|l|}{$\mathrm{R}^{2}=0.5957$} \\
\hline
\end{tabular}

prefectural government. Such data was obtained from the website of the National Land Numerical Information ${ }^{2}$ also. We assumed two factors of land price change as explanatory variables: population density and convenience of daily life. The population in 2010 is used as a population density factor. Elevation, distance from the town hall, community center, elementary school, hospitals, and bus stops are used as a convenience of daily life factor.

We used the equation to estimate a land price LP.

$$
L P \sum_{j=1}^{6} \alpha_{j} \cdot f_{j}+\beta
$$

where, $f$ is each explanatory variables, $\alpha$ is the regression coefficient and $\beta$ is the intercept.

Table 17.3 shows results of this analysis. The sign conditions of each of the coefficients are satisfied. Although the significance levels of three factors are not satisfied, coefficient of determination is 0.59 ; therefore, we used the model to estimate land price for all of the target areas. Figure 17.5 shows estimated land price.

Figure 17.5 shows two hot spots. These are located around Kainan Hospital and the town hall. This roadside area located between the town hall and station has many living facilities. The area is convenient to live. But most of the area is included in the river inundation area. Around Kainan Hospital, there is a community center and bus stops. The roadside area of national highway 55 near the hospital has some housing areas, but as with another hot spot, the area has river and surface water inundation risk also.

\footnotetext{
${ }^{2}$ https://nlftp.mlit.go.jp/ksj/
} 


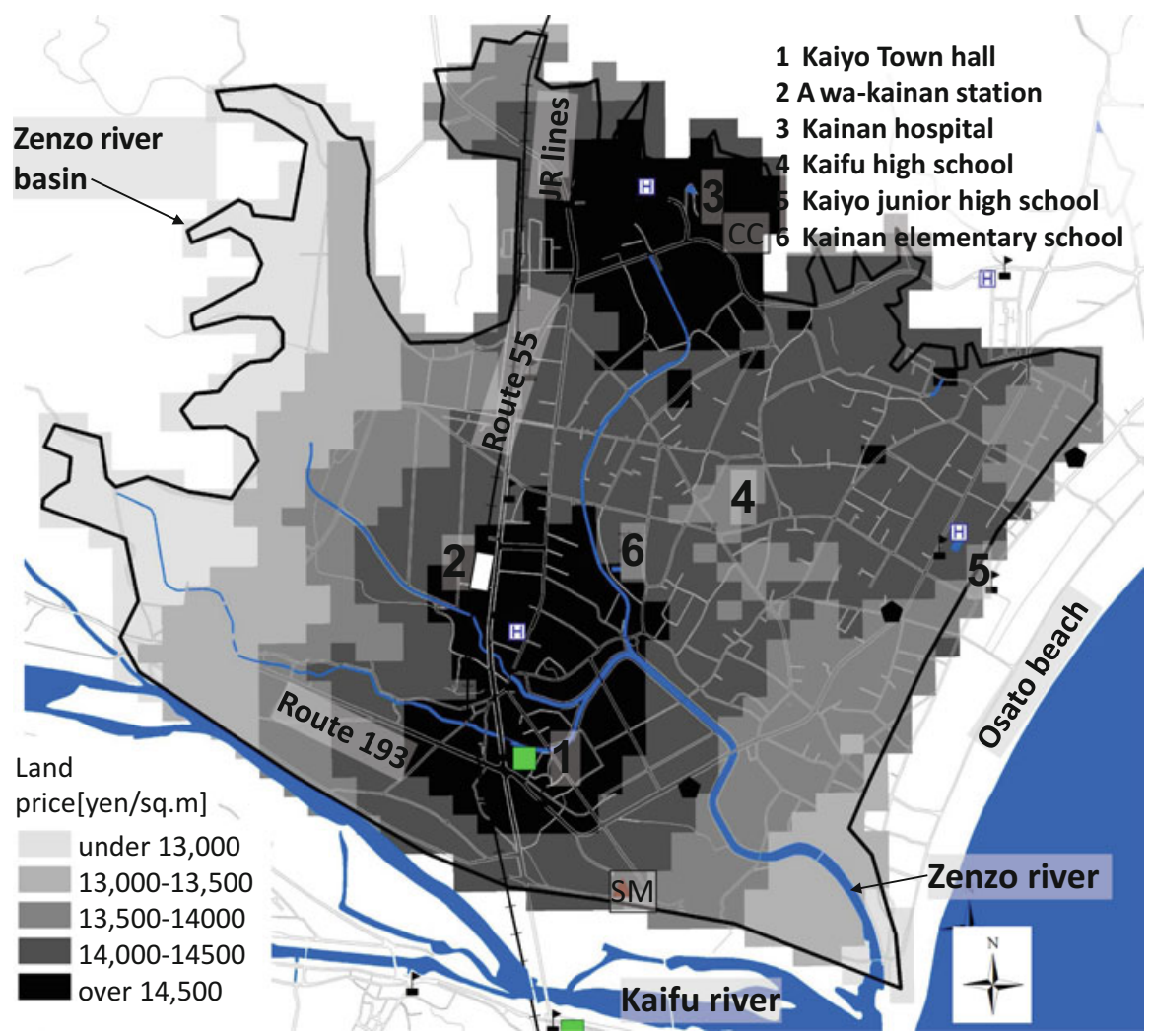

Fig. 17.5 Distribution of convenience level as estimated land price

\subsection{Classification of Target Area}

We classified the target area for each zone using risk 1 and risk 2, convenience level, area of paddy fields, farmland, vacant areas, pine forests, other forests, and elevation, by Ward's method of hierarchical cluster analysis by statistics software R. Figure 17.6 shows the results of classification using risk 1, and Fig. 17.7 shows the results of classification using risk 2 . Table 17.4 shows the average of data using cluster analysis for risk 1, and Table 17.5 shows the same data for risk 2 .

Comparing Figs. 17.6 and 17.7, it can be seen that the trend of classification shows the same pattern. Cluster 4 of risk 1 shows the same pattern of cluster 5 of risk 2 , and cluster 5 of risk 1 shows the same pattern of cluster 4 of risk 2 . 


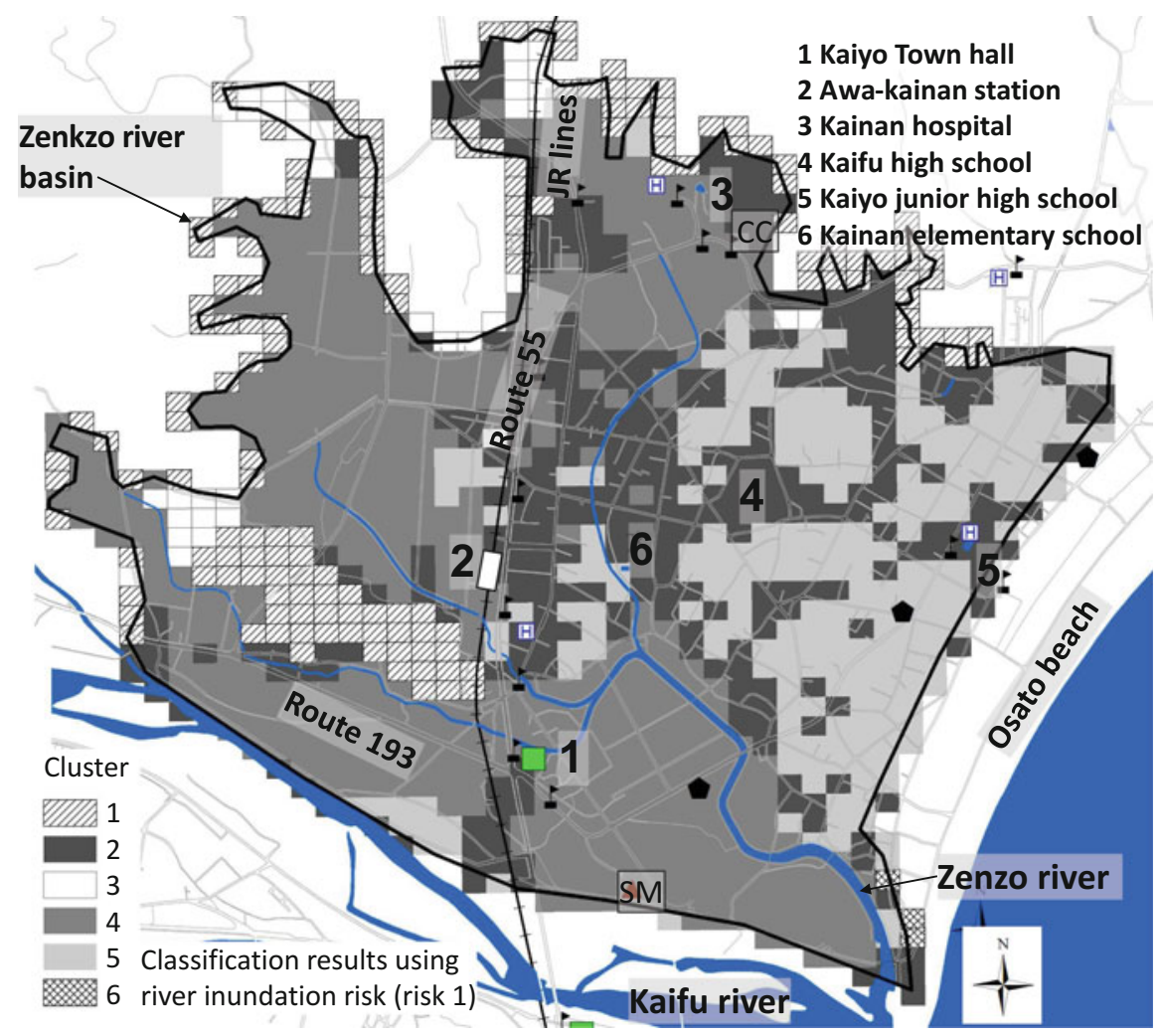

Fig. 17.6 Result of cluster analysis by risk 1

From these results, we can present the following land use trend:

1. Cluster 1 (zone 1).

Zone 1, which is classified with cluster 1, includes the forest area mainly. This zone should be preserved as a preservation area.

2. Cluster 2 (zone 2).

Zone 2, which is classified with cluster 2, includes the area with low inundation risk and high land price. Comparing Figs. 17.6 and 17.7, in the case of cluster 2 by risk 2, the area around the town hall is classified as cluster 2, but in the case of the same cluster for risk 1 , the area is classified as cluster 4 mainly. For this reason, it is thought that there is a difference of risk levels 1 and 2. The area around the station leading to Kaifu High School is classified in this cluster. Because there are many houses and shops in the area, this area is suitable for town center and housing area, after having the arrangement of evacuation environment and reinforcement of buildings. 


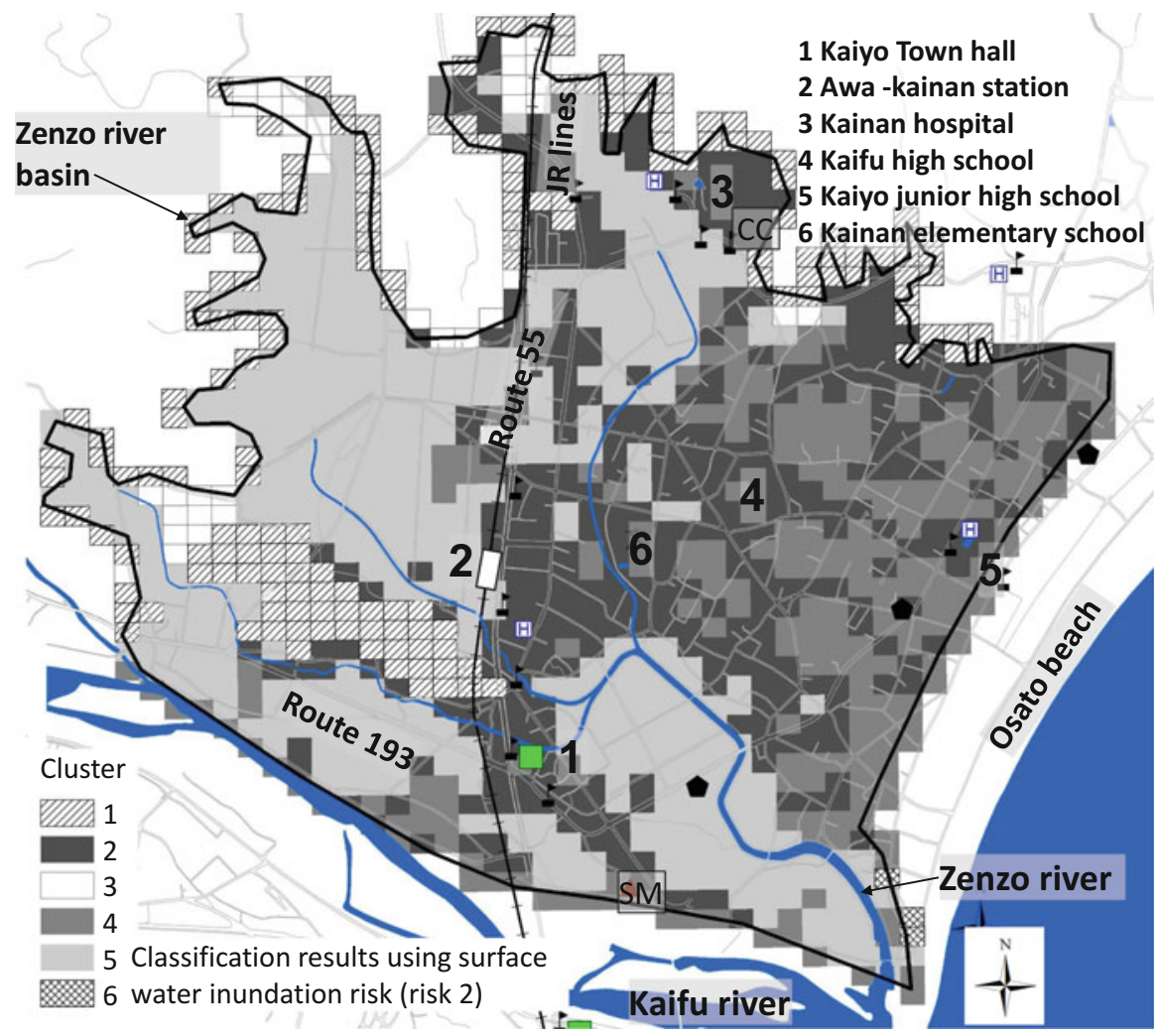

Fig. 17.7 Result of cluster analysis by risk 2

Table 17.4 Averages of the data using cluster analysis by risk 1

\begin{tabular}{|c|c|c|c|c|c|c|c|}
\hline & \multicolumn{6}{|l|}{ Cluster } \\
\hline & & 1 & 2 & 3 & 4 & 5 & 6 \\
\hline \multicolumn{2}{|c|}{ Damage level by river inundation } & 0.2 & 0.2 & 0.3 & 0.8 & 0.1 & 0.0 \\
\hline \multicolumn{2}{|c|}{ Elevation $[\mathrm{m}]$} & 20.1 & 6.6 & 10.4 & 4.4 & 8.1 & 8.1 \\
\hline \multicolumn{2}{|c|}{ Land price [yen/sq.m] } & 13421.4 & 14214.5 & 13159.7 & 13908.0 & 14052.1 & 12876.7 \\
\hline \multirow[t]{5}{*}{ Area of } & Paddy field[sq.m] & 170.8 & 204.4 & 234.2 & 1783.6 & 53.2 & 0.0 \\
\hline & Farmland[sq.m] & 13.7 & 103.6 & 9.1 & 75.1 & 1401.8 & 46.7 \\
\hline & Vacant area[sq.m] & 7.4 & 15.9 & 1417.6 & 7.5 & 2.2 & 0.0 \\
\hline & Pine forest[sq.m] & 0.0 & 2.5 & 0.0 & 0.0 & 0.6 & 1366.7 \\
\hline & Forest[sq.m] & 2271.8 & 105.1 & 593.3 & 63.3 & 12.2 & 0.0 \\
\hline
\end{tabular}


Table 17.5 Averages of the data using cluster analysis by risk 2

\begin{tabular}{|c|c|c|c|c|c|c|c|}
\hline & \multicolumn{6}{|l|}{ Cluster } \\
\hline & & 1 & 2 & 3 & 4 & 5 & 6 \\
\hline \multicolumn{2}{|c|}{$\begin{array}{l}\text { Damage level by surface water } \\
\text { inundation }\end{array}$} & 0.1 & 0.1 & 0.1 & 0.1 & 0.2 & 0.0 \\
\hline \multicolumn{2}{|c|}{ Elevation $[\mathrm{m}]$} & 19.4 & 6.4 & 10.4 & 7.8 & 4.4 & 8.1 \\
\hline \multicolumn{2}{|c|}{ Land price [yen/sq.m] } & 13440.6 & 14361.4 & 13159.7 & 13943.9 & 13818.9 & 12876.7 \\
\hline \multirow[t]{5}{*}{ Area of } & Paddy field[sq.m] & 195.7 & 140.2 & 234.2 & 131.6 & 1973.7 & 0.0 \\
\hline & Farmland[sq.m] & 12.7 & 250.6 & 9.1 & 1293.1 & 31.0 & 46.7 \\
\hline & Vacant area[sq.m] & 17.7 & 15.4 & 1417.6 & 0.3 & 4.0 & 0.0 \\
\hline & Pine forest[sq.m] & 0.0 & 0.0 & 0.0 & 1.1 & 1.5 & 1366.7 \\
\hline & Forest[sq.m] & 2206.6 & 97.7 & 593.3 & 1.6 & 35.1 & 0.0 \\
\hline
\end{tabular}

3. Cluster 3 (zone 3).

Zone 3 , which is classified as cluster 3 , includes the vacant area and upland mainly. Because this zone is surrounded by a green area and paddy fields, new development in this zone should be prohibited, and current land use should be maintained.

4. Cluster 4 with risk 1 and cluster 5 with risk 2 (zone 4).

Zone 4 which is classified with these clusters consists mainly of paddy fields. This cluster is overlapped with river and surface water inundation area. Because paddy fields have a storage and an infiltration function of rainwater, the cluster is important for mitigation of inundation disaster. Because it is easy to change paddy fields to the built-up area, as observed from past cases, new development in the zone should be prohibited.

5. Cluster 5 of risk 1 and cluster 4 of risk 2 (zone 5).

Zone 5 which is classified with the cluster includes the farmland with diffusive built-up area. This area is located in the east side of Kaifu High School mainly. Because the area is slightly elevated, inundation risk is very low. Farmland has a disaster mitigation function as with paddy fields. Therefore, it is important to keep farmland to protect the nearby housing area.

6. Cluster 6 (zone 6).

Zone 6, which is classified with the clusters, includes the pine forest mainly. Because pine trees are important to mitigate tsunami or wind disaster, it is important to maintain the present land use in zone 6 .

\subsection{Overlay Analysis}

In the target area, depopulation continues and the number of vacant houses is increasing. Considering this point, the area needs to become smaller for a viable urban form in the future. Observing the distribution of vacant houses is useful information with regard to discussion about the land use plan. For this reason, we 
developed an estimation model to show a probability that changes from occupied to vacant houses by logistic regression analysis.

Objective variable is the ratio of vacant houses in 2018, per 50 meter cell. In Japan, it is difficult to obtain location data of vacant houses, due to this being private information. We arranged individual house data from a commercial GIS database which is named Z-Map town2 (ZENRIN Co., Ltd.). This data includes the location and nameplates for all houses. From the database, as a vacant house, we selected the house complying with the condition of having no nameplate in 2018 , and we calculated the ratio of vacant houses.

As an explanatory variable, we assumed the following four factors: (1) inhabitant characteristics, (2) convenience level of living environment which is calculated in the model of Table 17.3, (3) area of houses, and (4) land use characteristics. Specifically, the number of inhabitants over 65 years of age is used to show the factor (1). The area of houses in 2006 is used to show the factor (3). The areas of paddy fields, farmland, and forest are used to show the factor (4). This estimation was carried out in the cell with houses in 2006.

We used the equation to estimate a probability $P v$ that changes from occupied to vacant houses.

$$
P v=1 /\left[1+\exp \left\{-\left(\sum_{j=1}^{7} \alpha_{j} \cdot f_{j}+\beta\right)\right\}\right]
$$

where, $f$ is each explanatory variables, $\alpha$ is the regression coefficient and $\beta$ is the intercept.

Table 17.6 shows the results of the analysis. The variables were selected by way of a stepwise method. As shown in Table 17.6, factors other than land use area and houses were not selected as significant variables. From this data, it is evident that with the smaller the area of houses, paddy fields, farmland, and green area, the probability of vacant houses will be larger. Because depopulation continues across the target area, the smaller house area the probability of vacant house will be high. Figure 17.8 shows the distribution of vacant houses which is estimated by the model. This figure shows that the probability in roadside area is about 0.4 . These areas are residential areas but include diffusive paddy field and farmland also. Therefore, the

Table 17.6 Result of the logistic regression analysis

\begin{tabular}{l|l|l|r|l|l}
\hline & Estimate $\left(* 10^{-3}\right)$ & Std. Error & z values & $\operatorname{Pr}(>|\mathrm{z}|)$ & \\
\hline Intercept & 391.7495 & 0.245 & 1.598 & 0.110 & \\
\hline Area of houses (2006) [sq.m] & -1.1701 & 0.000 & -2.354 & 0.019 & $*$ \\
\hline Area of paddy field (2006) [sq.m] & -0.4595 & 0.000 & -2.420 & 0.016 & $*$ \\
\hline Area of farmland (2006) [sq.m] & -0.4081 & 0.000 & -2.828 & 0.005 & $* *$ \\
\hline Area of forest (2006) [sq.m] & -0.4374 & 0.000 & -1.804 & 0.071 &. \\
\hline AIC $=758.46$
\end{tabular}




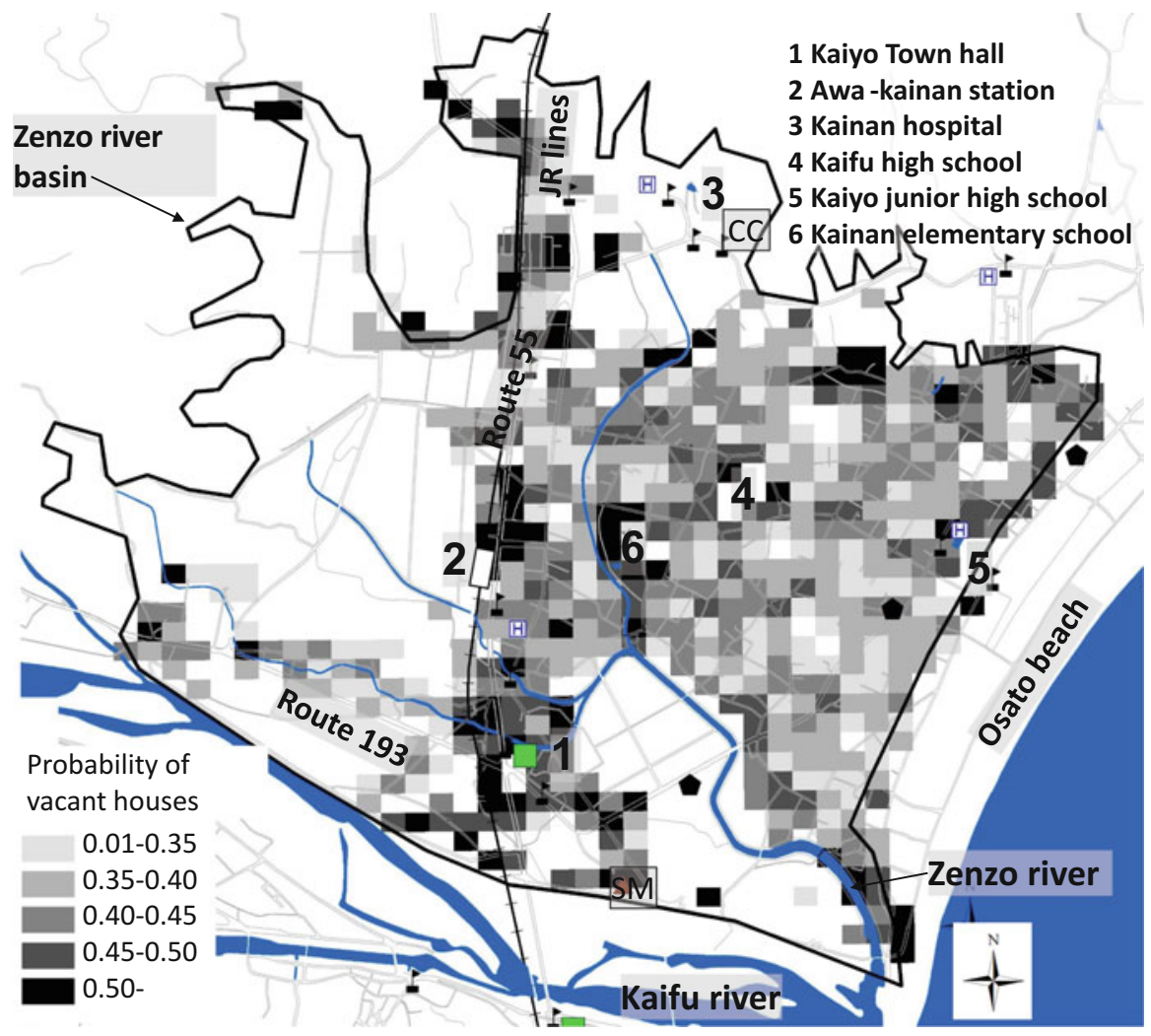

Fig. 17.8 Probability of vacant houses

probability is low. Because there are few houses in forest area, the probability is low. According to Fig. 17.8, a high probability area is observed mainly around the central built-up area and city hall. There are some areas of high probability near the elementary school also. These areas highlight the diffusive built-up area near the central area.

Figure 17.9 shows zone 2 with the probability of vacant houses over 0.5 . The selected area has low inundation risk with a high convenience level, and high probability of vacant houses. Areas in Fig. 17.9 have a possibility of continuing the development of new houses because these areas are located in the central builtup area. The target area needs to be a smaller more compact built-up area due to 


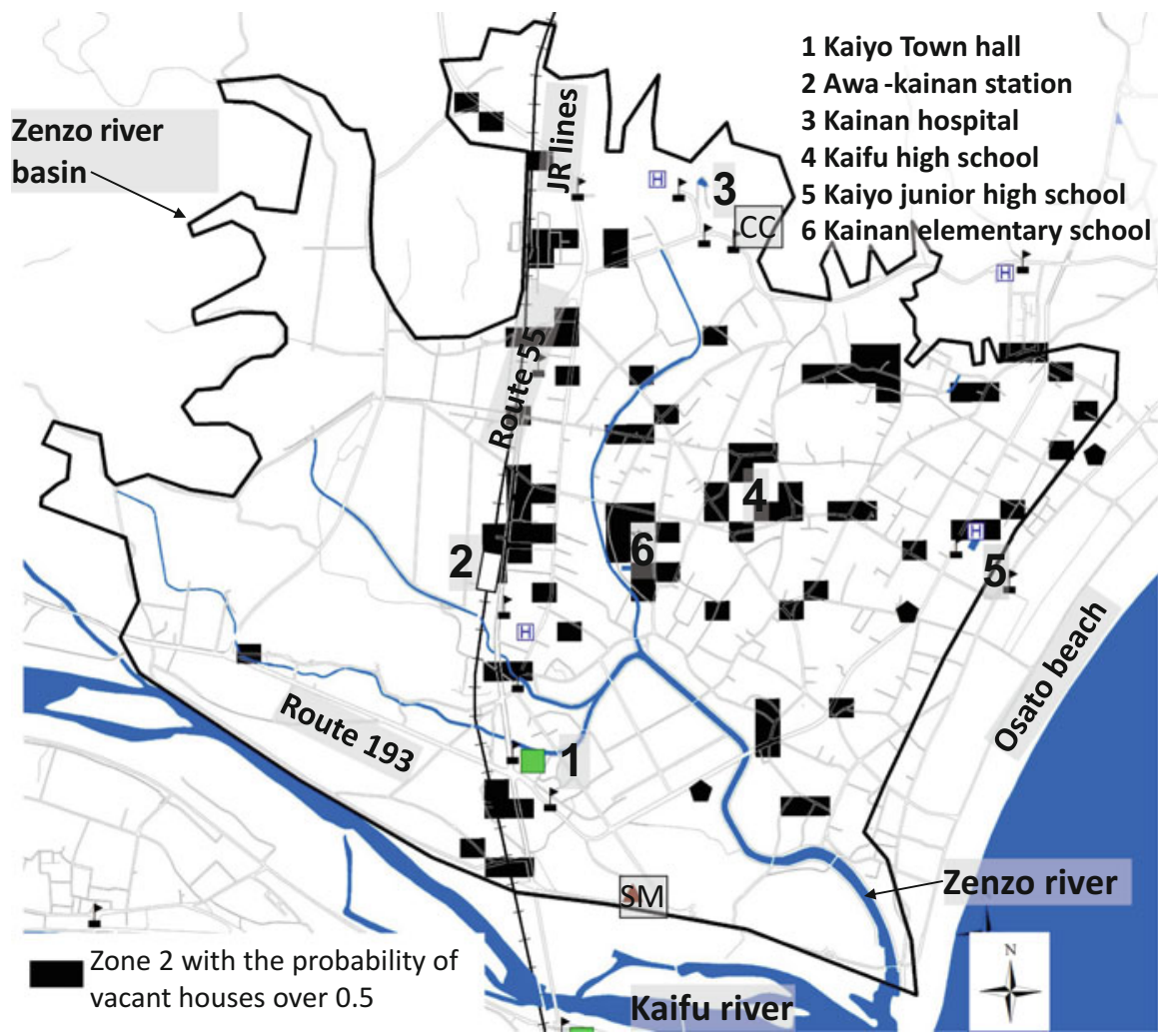

Fig. 17.9 Zone 2 with probability of vacant houses over 0.5

depopulation. Therefore, in the future, control of new development and change of vacant houses to natural land use like parks or farmland are necessary.

Figure 17.10 shows zone 4 with the probability of vacant houses over 0.5 . Because zone 4 includes many paddy fields, if vacant houses in the area will appear, these are better to be changed to natural land use.

Figure 17.11 shows zone 5 with the probability of vacant houses under 0.5 . The selected areas have low risk and low probability of vacant houses. Therefore, it is better to gather future housing mainly in this area. 


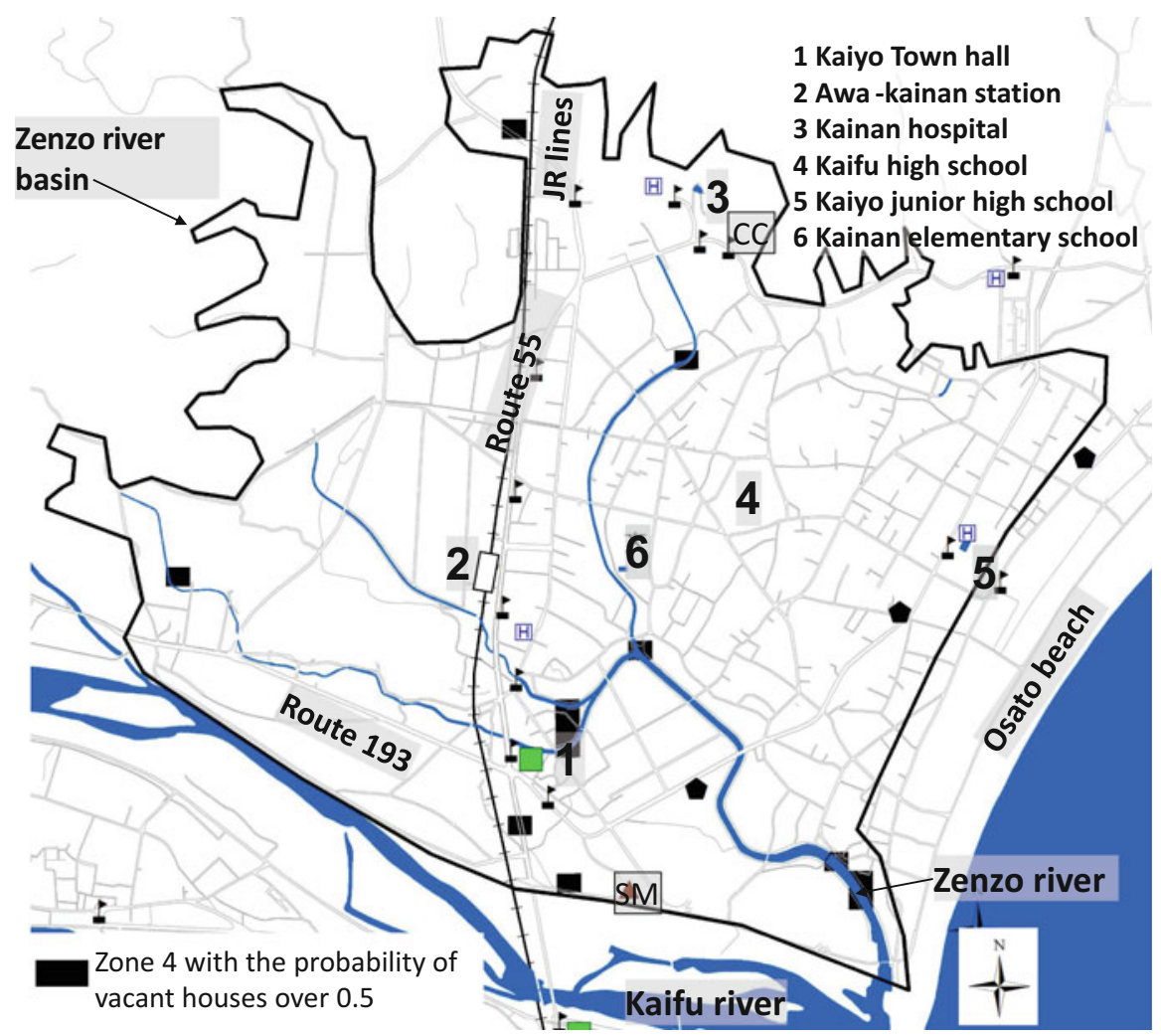

Fig. 17.10 Zone 4 with probability of vacant houses over 0.5

\subsection{Land Use Regulation in the Target Area}

Japanese national land is regulated by the National Land Use Planning Act. Five areas are specified in the act. These are urban area, agricultural area, forest area, nature park area, and nature conservation area. These areas are regulated by individual acts. There is no natural conservation area in the target area.

Land use in Japanese cities is regulated by the City Planning Act. In the act, designation of city planning area is required. This area is the same as in urban area. But the target area is not included in the designated city planning area, so it is difficult to control land use and buildings in the area.

Agricultural area is regulated by the Cropland Act. Because the target area is designated as an agricultural promotion area of the act, it is impossible for local government to control development in the area. But it is possible to change land use to other land use by satisfying some conditions. Figure 17.12 shows agricultural promotion area in the target area. This promotion area is overlapped by zone 4, so it is important to keep such an agricultural area. 


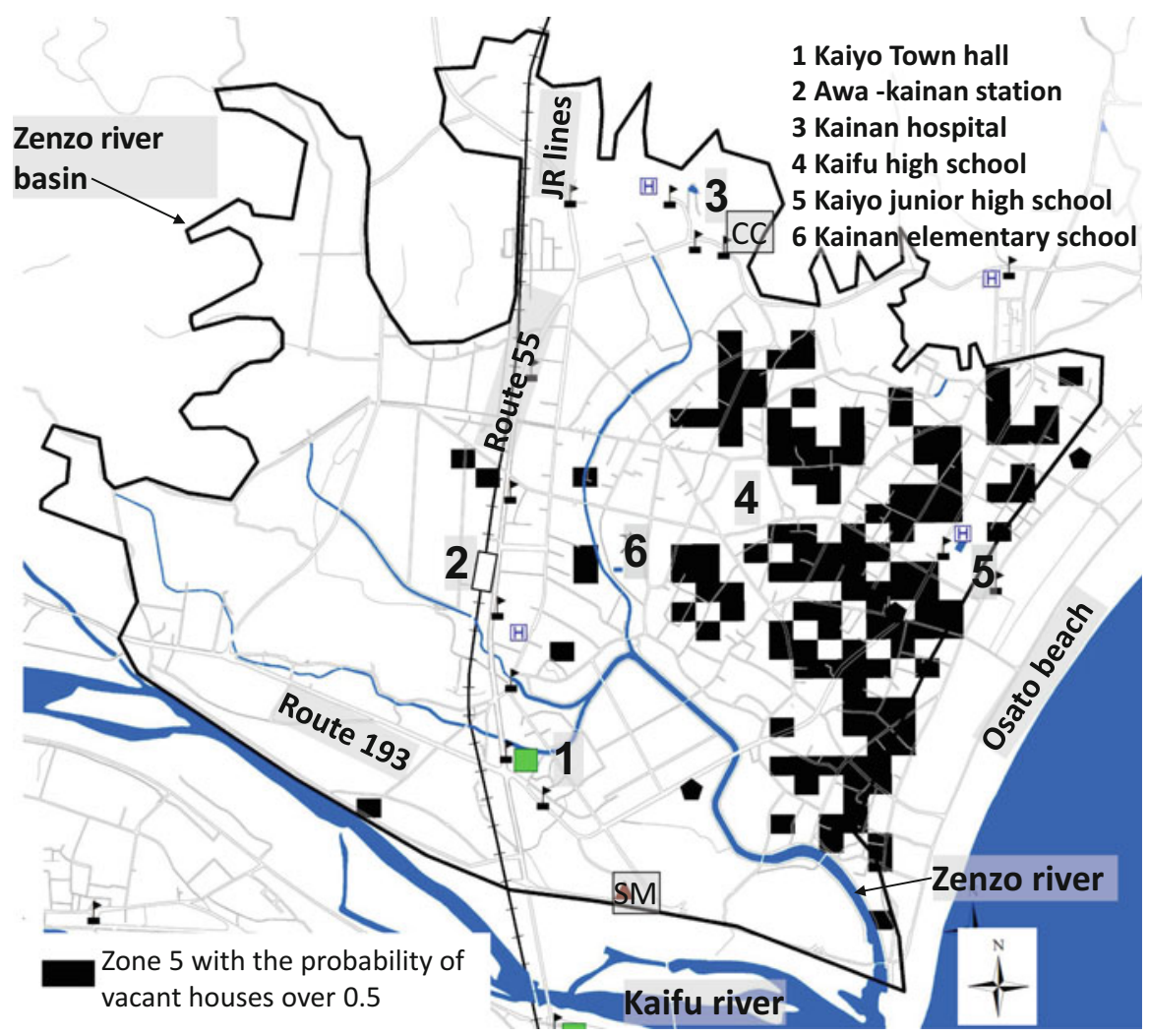

Fig. 17.11 Zone 5 with probability of vacant houses over 0.5

Forest area is regulated by the Forest Act. Around the mountainous area in the target area is designated as private forest of the regional forest plan, as shown in Fig. 17.12. Development in the forest requires permission from the local government. The target area is a depopulated town where there is little probability of any future large urban development. It is important to control small development in order to protect the forest area.

Nature Park is regulated by the Natural Parks Act. Osato beach in the target area is designated as a natural park area. This beach has an important role in GI in the target area, and continued management of this beach in the future is important.

Agricultural, forest, and beach areas are under legal control system, but there are no measures to manage them as built-up area or small agricultural area. The legal system is insufficient in the target area, and land use that should be included in the plans of local governments such as general master plan will be considered and the projects necessary for land use control will be promoted. 


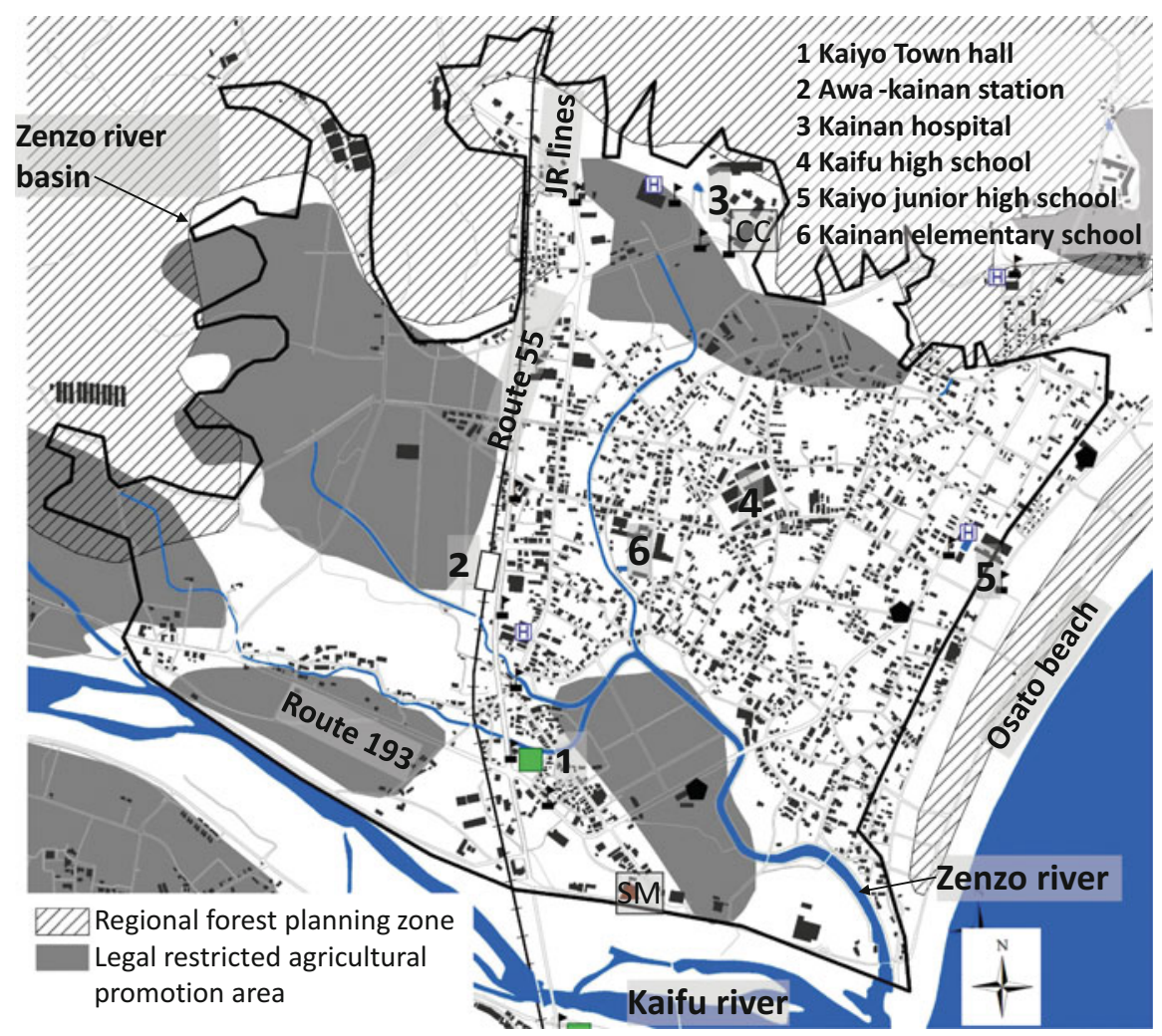

Fig. 17.12 Control area for farmland and forest

\subsection{Conclusion}

According to the second Japanese National Spatial Strategies of 2015, the concept of compact and resilient city is identified as an important strategy (Ministry of Land, Infrastructure, Transport and Tourism 2015). Recently, there have been many natural disasters in Japan, and rapid depopulation is continuing in many provincial towns and cities. In the future, such municipalities will be required to minimize the damage caused by disasters and reduce the scale to a suitable size in response to the declining population. In this study, we selected suitable areas using land characteristics classification and estimation of vacant houses probability as fundamental information for examining where and how to aggregate future, more compact built-up areas.

In the central area of the target area, although it is convenient, there is an inundation risk. Paddy fields on the west and south sides of the target area serve to help mitigate river and surface water inundation. Therefore, urban land use should be prohibited in such places. The eastern side near Osato beach is a lesser 
convenient place to live, but safer. Such a place should be a residential area by maintaining farmland and vacant areas as GI. Although the current central area is more convenient, there is a risk of river inundation; therefore, it is necessary to ensure safety by the condition of structures. Furthermore, from the viewpoint of increasing of living environment, it is also necessary to network the central area and surrounding residential areas by public transportation to eliminate movement restrictions. Important concepts for depopulated cities and towns in Japan are ensuring coexistence of disaster prevention using GI and retaining a comfortable living environment.

\section{References}

Chino M (2009) Tokei today no. 9 (short report by Statistics Bureau of Japan) (Japanese). https:// www.stat.go.jp/info/today/009.html

Disaster Management group in Cabinet office of Japan (2021) Guidelines for the criteria for recognizing damage to dwellings disasters (Japanese)

Ministry of Land, Infrastructure, Transport and Tourism (2015) 2nd. National Spatial Strategies in 2015 (Japanese). https://www.mlit.go.jp/common/001100233.pdf

Ministry of Land, Infrastructure, Transport and Tourism (2010) Statistics report of inundation disaster in 2010 (Japanese)

Muto Y, Kotani S, Miyoshi M, Kamada M, Tamura T (2018) Retarding capability change of wetland paddy fields due to house land development -utilizing paddy fields as green infrastructure. Proceedings of the 21th IAHR-APD congress 2018, Vol 2, 1209-1218

Tokushima Prefecture Government (2013) Secondary damage estimation of Nankai Trough earthquake in Tokushima prefecture (Japanese). https://anshin.pref.tokushima.jp/docs/ 2013112100023/

Yokokawa R, Muto Y, Kamada M, Tamura T (2020) Flood control function of farmland as green infrastructure using inundation analysis model. J Jpn Soc Civil Eng Ser B1 76:463-468. https:/ /repo.lib.tokushima-u.ac.jp/ja/115208

Open Access This chapter is licensed under the terms of the Creative Commons Attribution 4.0 International License (http://creativecommons.org/licenses/by/4.0/), which permits use, sharing, adaptation, distribution and reproduction in any medium or format, as long as you give appropriate credit to the original author(s) and the source, provide a link to the Creative Commons license and indicate if changes were made.

The images or other third party material in this chapter are included in the chapter's Creative Commons license, unless indicated otherwise in a credit line to the material. If material is not included in the chapter's Creative Commons license and your intended use is not permitted by statutory regulation or exceeds the permitted use, you will need to obtain permission directly from the copyright holder. 